\title{
Delayed graft function after kidney transplantation: is saline really responsible?
}

\author{
Gildas Gueret, MD, PhD (D) Pascale Le Maguet, MD • Renaud Fabre, MD • \\ Marc Laffon, MD, PhD
}

Received: 9 April 2020/Revised: 13 April 2020/Accepted: 14 April 2020/Published online: 11 May 2020

(c) Canadian Anesthesiologists' Society 2020

We read with interest the article entitled "Association between perioperative normal saline (NS) solution and delayed graft function (DGF) in deceased-donor kidney transplantation: a retrospective observational study". ${ }^{1}$ This article found that DGF was associated with perioperative NS infusion volume and not with hyperchloremia in deceased-donor kidney transplant recipients.

Nevertheless, we have some comments:

a The authors wrote that the "strong ion difference (SID) may better reflect the acidifying effects of large volumes of saline compared with direct measurement of serum chloride or bicarbonate." ${ }^{1}$ We agree that chloride alone is not enough to analyze acid-base disturbances in accordance with the Stewart theory. ${ }^{2}$ Nevertheless, in the Morgan study, ${ }^{3}$ chloride was replaced by bicarbonate. A direct relationship between SID, bicarbonate, and acidosis was found by the authors, but the exact mechanism of acidosis (SID or bicarbonate decrease) was not determined. In that study, SID was calculated as the difference between $\mathrm{Na}+$ and $\mathrm{Cl}-.{ }^{1} \mathrm{Nevertheless,} \mathrm{other} \mathrm{parameters} \mathrm{such} \mathrm{as}$ lactate and potassium were not included, and may have modified the SID value, particularly in case of hyperkalemia. $^{2}$

b Some preoperative parameters (catecholamine infusion, terminal creatinine, donor age, and cold ischemic time) were different between the two groups. When using

G. Gueret, MD, PhD $(\varangle) \cdot$ P. Le Maguet, MD $\cdot$ R. Fabre, MD

Service d'anesthésie, Centre Hospitalier de Quimper, Quimper, France

e-mail: gildas.gueret@gmail.com

M. Laffon, MD, $\mathrm{PhD}$

Département d'anesthésie réanimation, CHRU, Tours, France creatinine reduction as an outcome, NS volume was not a risk factor of DGF. So it's difficult to draw definite conclusions about NS and DGF.

c Perioperative NS infusion volume was associated with an increased risk of DGF. Nevertheless, the NS volume difference was low between the two groups (mean difference: $339 \mathrm{~mL}$ in the operating room, $169 \mathrm{~mL}$ in the intensive care unit [ICU]). Additionally, substantial variability existed between patients: DGF patients also received more buffered crystalloids (BC) and gelatin. Which BC were given, and what was the volume of $\mathrm{BC}$, total crystalloid, and gelatin received by the patients? As relative oliguria was an indication of fluid infusion, did DGF occur because patients received more NS, or did patients receive more fluid infusion (particularly NS) because they had oliguria and DGF? How many patients received furosemide?

The effect of hyperchloremia in clinical practice remains an active discussion, particularly in the $\mathrm{ICU}^{4}, 5$ and in high-risk patients such as those undergoing kidney transplantation. A clear relationship between the amount of chloride administered and kidney dysfunction has not yet been found in previous studies. ${ }^{4},{ }^{5}$ The study by Nesseler et $a l$ is an interesting study that highlights the role of chloride independently of acidosis in DGF. It confirms that the effects of chloride are probably more complex than previously thought, but the study doesn't allow us to definitively address the respective roles of NS and BC in kidney transplantation.

Disclosures None.

Funding statement None. 
Editorial responsibility This submission was handled by Dr. Philip M. Jones, Associate Editor, Canadian Journal of Anesthesia.

\section{References}

1. Nesseler N, Rached A, Ross JT, et al. Association between perioperative normal saline and delayed graft function in deceased-donor kidney transplantation: a retrospective observational study. Can J Anesth. 2020;67:421-9.

2. Gueret G, Fabre R, Le Maguet P, Laffon M. Hyperchlorémie et acidose métabolique : l'association est-elle réellement démontrée ? Anesthésie \& Réanimation. 2020. DOI: https://doi.org/10.1016/j. anrea.2019.12.002.
3. Morgan TJ, Venkatesh B, Hall J. Crystalloid strong ion difference determines metabolic acid-base change during in vitro hemodilution. Crit Care Med. 2002;30:157-60.

4. Semler $M W$, Self WH, Wanderer JP, et al. Balanced crystalloids versus saline in critically ill adults. N Engl J Med. 2018;378:82939.

5. Young P, Bailey $M$, Beasley $R$, et al. Effect of a buffered crystalloid solution vs saline on acute kidney injury among patients in the intensive care unit: the SPLIT randomized clinical trial. JAMA. 2015;314:1701-10.

Publisher's Note Springer Nature remains neutral with regard to jurisdictional claims in published maps and institutional affiliations. 